\title{
Differential costs of sexual and vegetative reproduction in wild strawberry populations
}

\author{
Thomas W. Jurik * \\ Section of Ecology and Systematics, Cornell University, Ithaca, N.Y. 14853, USA
}

\begin{abstract}
Summary. The $\mathrm{CO}_{2}$ costs of producing sexual and vegetative reproductive propagules were calculated for two species of wild strawberry, Fragaria virginiana and $F$. vesca. Five populations on sites representing a gradient of successional regrowth near Ithaca, New York, USA, were studied for two or three years each. Field studies of phenology, biomass, demography, and environment and laboratory studies of $\mathrm{CO}_{2}$ exchange were integrated using a computerbased model of $\mathrm{CO}_{2}$ dynamics to estimate costs of propagules.

The percentage of plants flowering and the number of flower buds produced were highest in an open, recently disturbed habitat and lowest in a forest habitat. The openhabitat plants had the greatest success in converting flower buds into ripe fruits and also produced the highest numbers of runners and runner plantlets. On the basis of total investments in structure and respiration minus any photosynthetic gain of all reproductive structures, the cost per seed was lowest in the most open habitats and highest and increasingly variable in the more closed habitats. The cost of plantlets also was lowest in the most open habitat. The differences among habitats in cost of plantlets alive after one or two growing seasons increased due to differential survivorship of plantlets, with the open habitat continuing to have the lowest cost per plantlet. Theoretical treatments of life history characteristics such as reproductive effort should recognize that costs of equivalent type and size of propagule may vary among environments.
\end{abstract}

Population biologists have over the past decade devoted much attention to reproductive effort, the fraction of an organism's resources devoted to reproduction. Reproductive effort is a convenient summary of an organism's reproductive activities. Such summarization, however, can divert attention from the underlying components of reproduction. Investigation of the actual costs of producing complete reproductive propagules and of the actual number of propagules produced may reveal aspects of the reproductive process and the underlying selective forces that are hidden in the simple calculation of reproductive effort.

I have previously (Jurik 1980, 1983) reported reproductive effort including metabolic and structural costs of five wild strawberry populations over a range of habitats. This

\footnotetext{
* Present address: University of Michigan Biological Station, 4053 Natural Science, Ann Arbor, MI 48109-1048, USA
}

spatial sequence of habitats corresponds to the temporal sequence of habitats strawberry plants may experience as successional regrowth overtops a population that has colonized an open site created by some disturbance. Here, I analyze the components of achieved reproductive output of the populations and show that the costs of propagules of equivalent initial value may vary according to environment. Such variable costs lead to conclusions about observed levels of reproductive effort that differ from conclusions based on shifting advantage of sexual and vegetative reproduction.

\section{Methods}

Field data on biomass, phenology, and microclimate were combined with laboratory measurements of $\mathrm{CO}_{2}$ exchange of reproductive structures using a model that created a relatively continuous simulation of plant growth and environment. Photosynthesis, respiratory costs, and structural costs were calculated using results of simulations for different populations. Carbon cost data were then combined with survivorship data to calculate costs of propagules of different ages. Carbon was chosen as the unit of cost currency because calculations of yearly strawberry plant carbon budgets indicate that carbon gain is a major factor regulating strawberry growth (Jurik 1980, 1983).

Previous analyses (Jurik 1980, 1983) indicate that, for calculation of total $\mathrm{CO}_{2}$ fluxes, accurate determination of biomass and longevity of biomass are as important, if not more so, as determination of rates of photosynthesis and respiration. Thus, time of appearance, number, size, and longevity of reproductive structures, as well as $\mathrm{CO}_{2}$ exchange rates, are presented in detail here as the bases for calculations of $\mathrm{CO}_{2}$ fluxes.

\section{Field studies}

Fragaria virginiana Duchesne and F. vesca L. (Rosaceae) were studied from 1976 through May 1979. Field sites near Ithaca, New York, USA, were selected to represent five distinct stages of succession and types of physical environment. The field sites are described in detail in Jurik (1980, 1983), with general features given here. All vegetation and some soil on the most open site (OPEN) had been removed in 1974. An old-field that probably was used as a hayfield until 15 to 20 years before this study provided several other different microhabitats. The Old-field Herbaceous (HERB) site was completely covered by herbs but was relatively 
open, with few plants taller than the strawberries. The Oldfield Transitional (TRANS) site was between several large shrubs and had complete cover of herbaceous plants larger than the strawberries. The Old-field SHRUB site was underneath a large shrub, with few herbs other than strawberry. The FOREST site was in a mesic forest that was at least partially cut not less than 70 years ago but that has been largely undisturbed since then. $F$. virginiana, which is typically found in a variety of habitats, was studied at the OPEN and Old-field sites. $F$. vesca, which is typically restricted to forest environments, was studied at the FOREST site. Both species reproduce sexually via seed and vegetatively via runner plantlets.

Biomass dynamics at each site were monitored by marking every reproductive and aboveground vegetative structure of plants that were individually identified and tracked through the study years. Observations were made at intervals ranging from every six to ten days in the spring to every four to five weeks in the late summer and fall. The size of each organ was estimated by measuring it on each visit, until no growth had occurred for several visits. For runners and plantlets, these measures were converted to mass or area units by means of regression equations developed from measurements and harvests of plants collected near the permanently marked plants. Flower bud, flower, and fruit masses were estimated from size and mass relationships derived from plants near the permanent study plants and from the organs used in $\mathrm{CO}_{2}$ exchange measurements (see below). The OPEN, Old-field SHRUB, and FOREST sites were surveyed on each visit for the appearance of seedlings. It is possible that seedlings could have emerged and died between censuses.

\section{Microenvironments}

Measurements of microclimate at each site were correlated with the more extensive but less detailed records of the Cornell University (Department of Agronomy) weather station to produce environmental data sets describing the conditions at each site (see Jurik 1980, 1983). The greatest difference among the sites was in amount of light received during the growing season. Daily integrated quantum flux was always highest at the OPEN site and successively lower at the Old-field HERB, Old-field TRANS, Oldfield SHRUB, and FOREST sites; daily totals in June were approximately $40,14,10,5$ and $3.5 \mathrm{~mol} \mathrm{~m}^{-2}$ day $^{-1}$, respectively (see Jurik 1983). Air temperatures varied little among the sites, with the FOREST site typically having slightly $\left(\sim 1^{\circ} \mathrm{C}\right)$ lower maximum temperatures and higher minimum temperatures (see Jurik 1980).

\section{$\mathrm{CO}_{2}$ Exchange rates}

$\mathrm{CO}_{2}$ exchange rates were measured using an infrared gas analyzer in an open-circulation system as described previously (Jurik 1980; Jurik et al. 1982). For measurements on sexual reproductive structures, a $125-\mathrm{ml}$ volume chamber was substituted for the leaf cuvette. Plant material was gathered from $F$. virginiana plants growing immediately behind Cornell University's Langmuir Laboratory in an old-field area, so that measurements were begun 5-10 min after collection. For each measurement, a total of 5-50 buds, flowers, or fruits was detached from several plants. To minimize wound respiration, each pedicel was severed
3-5 $\mathrm{mm}$ beneath the bracts, so only a very small portion of the tissue was damaged. Water vapor pressure was maintained just below the dewpoint, to minimize drying of the plant tissues.

For measurements on runner stems, a sod of earth including a plant with runners was brought into the laboratory from the field. The runner stem material, excluding plantlets, was measured in the leaf cuvette. The measurements thus included material of various ages. $\mathrm{CO}_{2}$ exchange of plantlets was calculated from measurements on leaves and from estimates for roots and crown following the procedure used for whole plants (see Jurik 1980, 1983).

\section{Calculation of $\mathrm{CO}_{2}$ dynamics}

$\mathrm{CO}_{2}$ dynamics of reproductive structures were calculated from the field and laboratory data using the model PLANT. PLANT and its application to strawberry was described in Jurik (1980, 1983), with certain general features given here.

PLANT simulates the carbon budget of a plant in terms of the $\mathrm{CO}_{2}$ required for the construction and maintenance of various parts of the plant. The $\mathrm{CO}_{2}$ costs of producing biomass of given composition, the respiratory costs of maintaining that biomass, and estimates of photosynthetic $\mathrm{CO}_{2}$ uptake are calculated. PLANT is a "bookkeeping" model that associates physiological rates with biomass values completely specified by the input data; the model does not have a set of rules for "growing" a plant but simply tracks plant size as specified from field data. Each day is divided into several intervals in which environmental conditions are assumed to be constant. Environmental data sets are created from field measurements and weather station records.

The production of plantlets as the vegetative reproductive units of strawberry creates some problems in determining the true costs to the parent plant. Both my calculations using PLANT and experimental evidence (my unpublished observations, and Smith 1972) indicate that, after some initial investment by the parent plant, a plantlet sometimes becomes a self-supporting entity early in the growing season. Furthermore, the first plantlet often can at least partially support the future growth of the runner stem and succeeding plantlets. In such cases, inclusion of the metabolic budgets of all the plantlets as part of the parent plant's could be justified as giving a broad picture of total metabolic activity, but this obscures actual costs to the parent. A1ternatively, one can include metabolism of the plantlets only to the point when the plantlets become independent; this gives a clearer picture of costs to the parent. It is, however, valid to consider the total number of plantlets produced as the return on the initial investment, when considering costs and benefits of allocation patterns. Here, the carbon dynamics and growth of a runner plantlet in a given environment were simulated using PLANT following the procedure used for parent plants described in Jurik (1983). Daily photosynthesis and total growth and respiration costs were calculated for the lifetime of the plantlet. The plantlet was declared independent of the parent plant on the first day of a period of at least seven days on which photosynthesis was greater then total costs on each day. The cost to the parent plant of producing runners and plantlets was calculated as the sum of: 1) the total costs incurred during the lifetime of the runner stems leading to the initial plantlet(s), 


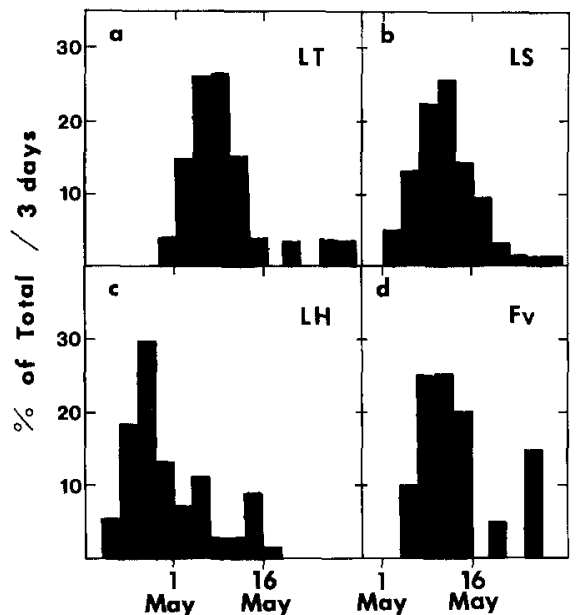

Fig. 1 a-d. Time of appearance of flower buds, 1978. Graphs show the proportion (in \%) of flower buds appearing (first becoming visible) in each 3-day interval. Percentages are based on the total number of flower buds produced by the given population. a Oldfield TRANS, b Old-field SHRUB, c Old-field HERB, d $F$. vesca (FOREST)

and 2) the total costs incurred until the plantlet(s) and any further runner growth became self-supporting.

\section{Results}

\section{Flower buds, flowers, and fruits}

Flower buds of Fragaria spp. are induced in the fall by declining photoperiods (Darrow 1966), with flowering and fruiting occurring the next spring. The time of first flower bud appearance varied slightly from spring to spring. In 1978, buds appeared continuously from mid-April to late May (Fig. 1). Although not studied in 1978, the OPEN population produced flower buds as early or earlier than the other populations, in 1976 and 1977.

The average time spent in each stage of development in 1978 is shown in Table 1. The green fruit stage is defined as starting when the pistils have noticeably started enlarging, usually soon after the flower has lost its petals. The ripe fruit stage begins when the fruit turns from white-pink to orange-red. The time required for a flower bud to become an open flower was about the same in all populations, with the Old-field SHRUB population requiring slightly fewer days. The times required for open flowers to become green fruits were similar for all populations, but the Old-field HERB population required less time for green fruits to become ripe fruits.

Flower dry mass and equations for calculation of fruit dry masses are given in the Appendix, as are percentages of plants with hermaphrodite and staminate flowers. The number of sexual reproductive organs produced per plant and their success in completing development varied within and among populations (Table 2). The means taken over all plants in each population typically had high standard deviations (coefficient of variation for flower buds ranged from 63 to $414 \%$, Table 2), and there were greater differences among the populations in mean number of ripe fruits produced per plant than in mean number of flower buds. Differences in the percentage for each population of plants producing at least one flower bud (Table 3) account for much of the variation among populations in mean number of flower buds produced. The mean numbers of flower buds per plant based only on flowering plants (Table 2) were of course higher than the means over all plants, but also tended to vary less among the populations and from year to year (coefficient of variation ranged from 24 to $65 \%$, Table 2). The $F$. vesca population typically produced fewer flower buds per flowering plant than the $F$. virginiana populations.

The success of flower buds in completing development into ripe fruits differed among the populations and from year to year (Table 4). All populations had high success in transformation of flower buds to open flowers. Given the high success of bud-flower transitions, the percentage of bud-green fruit transitions was largely determined by differences in the percent of flowers becoming green fruits. There was considerable variation in the success of green fruits in becoming ripe fruits in the Old-field TRANS, Oldfield SHRUB, and $F$. vesca populations. This may be due to the effect of smaller sample sizes on the percentage calculations for these populations, but probably also represented year-to-year and intrapopulation variation.

The considerable variation within populations in sexual reproduction is possibly due to patterns of cyclic reproduction of any one plant over several years (Jurik 1980). Plants may flower or produce runners in one year and then possi-

Table 1. Transition times between various stages of sexual reproductive development, 1978. Values in the same row followed by the same letter are not significantly different ( $p>0.05$; Student-Newman-Keuls test). No letters are given in rows with no significant differences

\begin{tabular}{|c|c|c|c|c|c|c|c|c|c|c|c|c|}
\hline \multirow[t]{2}{*}{ Days required for: } & \multicolumn{3}{|c|}{ Old-field HERB } & \multicolumn{3}{|c|}{ Old-field TRANS } & \multicolumn{3}{|c|}{ Old-field SHRUB } & \multicolumn{3}{|c|}{ F. vesca (FOREST) } \\
\hline & Days & S.D. & $N$ & Days & S.D. & $N$ & Days & S.D. & $N$ & Days & S.D. & $N$ \\
\hline New bud to bud gone & 25.0 & \pm 10.8 & 10 & 23.3 & \pm 5.9 & 9 & 26.4 & \pm 15.2 & 5 & - & - & 0 \\
\hline New bud to open flower & $19.1^{\mathrm{a}, \mathrm{b}}$ & \pm 6.1 & 34 & $19.3^{\mathrm{a}, \mathrm{b}}$ & \pm 3.7 & 7 & $15.9^{\mathrm{b}}$ & \pm 3.6 & 52 & $20.4^{\mathrm{a}}$ & \pm 8.4 & 14 \\
\hline New bud to green fruit & 28.3 & \pm 6.9 & 46 & 24.8 & \pm 4.0 & 5 & 26.5 & \pm 3.0 & 23 & 25.8 & \pm 2.8 & 17 \\
\hline New bud to ripe fruit & $52.4^{\mathrm{b}}$ & \pm 9.2 & 26 & $54.8^{\mathrm{a}, \mathrm{b}}$ & \pm 5.5 & 5 & $61.8^{\mathrm{a}}$ & \pm 2.4 & 13 & $60.0^{\mathrm{a}, \mathrm{b}}$ & \pm 1.0 & 3 \\
\hline Open flower to flower gone & - & - & 0 & 18.0 & - & 1 & 9.8 & \pm 5.2 & 4 & - & - & 0 \\
\hline Open flower to flower withered & 17.4 & \pm 5.8 & 12 & 20.6 & \pm 4.8 & 12 & 23.5 & \pm 8.6 & 25 & 14.0 & \pm 21.3 & 3 \\
\hline Open flower to green fruit & 8.8 & \pm 2.0 & 21 & 5.0 & - & 1 & 11.0 & \pm 2.7 & 24 & 8.3 & \pm 1.7 & 11 \\
\hline Green fruit to green fruit gone & 18.6 & \pm 4.7 & 18 & 33.0 & - & 1 & 25.9 & \pm 5.2 & 8 & 28.7 & \pm 6.2 & 14 \\
\hline Green fruit to ripe fruit & $25.3^{\mathrm{b}}$ & \pm 3.2 & 25 & $31.3^{\mathrm{a}}$ & \pm 2.8 & 4 & $34.8^{\mathrm{a}}$ & \pm 2.4 & 14 & $33.0^{\mathrm{a}}$ & \pm 2.0 & 3 \\
\hline Ripe fruit to ripe fruit gone & $4.5^{\mathrm{b}}$ & \pm 1.5 & 26 & $6.8^{a, b}$ & \pm 1.9 & 4 & $6.5^{\mathrm{a}, \mathrm{b}}$ & \pm 2.5 & 11 & $8.3^{a}$ & \pm 0.6 & 3 \\
\hline Ripe fruit to ripe fruit dry & - & - & 0 & 4.0 & - & 1 & 11.0 & \pm 6.0 & 3 & - & - & 0 \\
\hline
\end{tabular}


Table 2. Mean number of flower buds and ripe fruits produced per plant in each population, based on all plants and on flowering plants only. (S.D. $=$ Standard Deviation; C.V. = Coefficient of Variation)

\begin{tabular}{|c|c|c|c|c|c|c|c|c|c|c|c|c|c|c|c|}
\hline \multirow[t]{2}{*}{ Site } & \multirow[t]{2}{*}{ Year } & \multicolumn{7}{|c|}{ All plants } & \multicolumn{7}{|c|}{ Flowering plants only } \\
\hline & & $\begin{array}{l}\text { \# } \\
\text { plants }\end{array}$ & $\begin{array}{l}\# \\
\text { flower } \\
\text { buds }\end{array}$ & S.D. & $\begin{array}{l}\text { C.V. } \\
(\%)\end{array}$ & $\begin{array}{l}\# \\
\text { ripe } \\
\text { fruits }\end{array}$ & S.D. & $\begin{array}{l}\text { C.V. } \\
(\%)\end{array}$ & $\begin{array}{l}\# \\
\text { plants }\end{array}$ & $\begin{array}{l}\# \\
\text { flower } \\
\text { buds }\end{array}$ & S.D. & $\begin{array}{l}\text { C.V. } \\
(\%)\end{array}$ & $\begin{array}{l}\# \\
\text { ripe } \\
\text { fruits }\end{array}$ & S.D. & $\begin{array}{l}\text { C.V. } \\
(\%)\end{array}$ \\
\hline OPEN & $\begin{array}{l}1976 \\
1977\end{array}$ & $\begin{array}{l}25 \\
25\end{array}$ & $\begin{array}{l}4.3 \\
4.4\end{array}$ & $\begin{array}{l} \pm 4.0 \\
\pm 3.7\end{array}$ & $\begin{array}{l}93 \\
84\end{array}$ & $\begin{array}{l}3.3 \\
2.7\end{array}$ & $\begin{array}{l} \pm 3.2 \\
\pm 2.8\end{array}$ & $\begin{array}{r}97 \\
104\end{array}$ & $\begin{array}{l}15 \\
20\end{array}$ & $\begin{array}{l}7.1 \\
5.5\end{array}$ & $\begin{array}{l} \pm 2.3 \\
\pm 3.3\end{array}$ & $\begin{array}{l}32 \\
60\end{array}$ & $\begin{array}{l}5.5 \\
3.4\end{array}$ & $\begin{array}{l} \pm 2.1 \\
\pm 2.7\end{array}$ & $\begin{array}{l}38 \\
79\end{array}$ \\
\hline $\begin{array}{l}\text { Old-field } \\
\text { TRANS }\end{array}$ & $\begin{array}{l}1976 \\
1977 \\
1978 \\
1979\end{array}$ & $\begin{array}{l}23 \\
22 \\
22 \\
22\end{array}$ & $\begin{array}{l}3.7 \\
2.3 \\
1.6 \\
2.8\end{array}$ & $\begin{array}{l} \pm 3.4 \\
\pm 2.6 \\
\pm 2.7 \\
\pm 3.5\end{array}$ & $\begin{array}{r}92 \\
113 \\
169 \\
125\end{array}$ & $\begin{array}{l}0.3 \\
0.04 \\
0.2 \\
-\end{array}$ & $\begin{array}{l} \pm 0.8 \\
\pm 0.2 \\
\pm 0.7 \\
-\end{array}$ & $\begin{array}{l}267 \\
500 \\
350 \\
-\end{array}$ & $\begin{array}{r}14 \\
12 \\
8 \\
5\end{array}$ & $\begin{array}{l}6.0 \\
4.4 \\
4.5 \\
5.3\end{array}$ & $\begin{array}{l} \pm 2.0 \\
\pm 1.9 \\
\pm 2.7 \\
\pm 3.1\end{array}$ & $\begin{array}{l}33 \\
43 \\
60 \\
58\end{array}$ & $\begin{array}{l}2.1 \\
0.08 \\
0.6 \\
-\end{array}$ & $\begin{array}{l} \pm 3.3 \\
\pm 0.3 \\
\pm 1.1 \\
-\end{array}$ & $\begin{array}{l}157 \\
375 \\
183 \\
-\end{array}$ \\
\hline $\begin{array}{l}\text { F. vesca } \\
\text { (FOREST) }\end{array}$ & $\begin{array}{l}1976 \\
1977 \\
1978 \\
1979\end{array}$ & $\begin{array}{l}45 \\
20 \\
18 \\
16\end{array}$ & $\begin{array}{l}1.0 \\
0.7 \\
1.1 \\
0.6\end{array}$ & $\begin{array}{l} \pm 1.8 \\
\pm 1.3 \\
\pm 1.5 \\
\pm 1.1\end{array}$ & $\begin{array}{l}180 \\
186 \\
136 \\
183\end{array}$ & $\begin{array}{l}0.5 \\
0.4 \\
0.2 \\
-\end{array}$ & $\begin{array}{l} \pm 0.9 \\
\pm 0.9 \\
\pm 0.4 \\
-\end{array}$ & $\begin{array}{l}180 \\
225 \\
200 \\
-\end{array}$ & $\begin{array}{r}14 \\
5 \\
7 \\
4\end{array}$ & $\begin{array}{l}3.2 \\
2.6 \\
2.9 \\
2.3\end{array}$ & $\begin{array}{l} \pm 1.8 \\
\pm 1.1 \\
\pm 0.9 \\
\pm 1.0\end{array}$ & $\begin{array}{l}56 \\
42 \\
31 \\
43\end{array}$ & $\begin{array}{l}1.6 \\
1.6 \\
0.4 \\
-\end{array}$ & $\begin{array}{l} \pm 1.1 \\
\pm 1.1 \\
\pm 0.5 \\
-\end{array}$ & $\begin{array}{r}69 \\
69 \\
125 \\
-\end{array}$ \\
\hline
\end{tabular}

Table 3. Percentages of plants producing flowers or runners

\begin{tabular}{lcllll}
\hline Site & Year & $\begin{array}{l}\% \\
\text { pro- } \\
\text { ducing } \\
\text { flowers }\end{array}$ & $\begin{array}{l}\% \\
\text { pro- } \\
\text { ducing } \\
\text { runners }\end{array}$ & $\begin{array}{l}\text { \% ever flowering } \\
\text { during the study } \\
\text { period of }(N) \text { years }\end{array}$ \\
\hline OPEN & 1976 & 60 & 96 & & \\
Old-field & 1977 & 80 & 56 & 88 & $(2)$ \\
HERB & 1977 & 71 & 64 & & \\
& 1978 & 64 & 21 & 93 & $(2)$ \\
Old-field & 1979 & 85 & - & 100 & $(3)$ \\
TRANS & 1976 & 61 & 65 & & \\
& 1977 & 52 & 9 & 74 & $(2)$ \\
& 1978 & 36 & 27 & 78 & $(3)$ \\
Old-field & 1979 & 23 & - & 78 & $(4)$ \\
SHRUB & 1976 & 6 & 71 & & \\
& 1977 & 73 & 20 & 73 & $(2)$ \\
& 1978 & 60 & 13 & 80 & $(3)$ \\
F. vesca & 1979 & 53 & - & 87 & $(4)$ \\
(FOREST) & 1976 & 31 & 60 & & \\
& 1977 & 25 & 30 & 35 & $(2)$ \\
& 1979 & 25 & 56 & 38 & $(3)$ \\
\hline
\end{tabular}

bly require one or more years for accumulating reserves before reproduction is again possible. Table 3 shows the percentage of plants in each population flowering at least once during the course of this study. About $90 \%$ of the OPEN and Old-field HERB plants had flowered after only two years, while the other populations took longer to approach this level. After four years, fewer than half the $F$. vesca plants had flowered. This suggests that flowering is progressively more difficult over the sequence of habitats, when viewed in terms of cumulative yearly performance.

\section{Runners and plantlets}

Runner production occurred from early May to August (Fig. 2). The number of runners initiated per plant varied both among the populations and among years (Table 5). All populations produced more runners in 1976 than in any other year. Much of the increase for the OPEN population was due to higher runner production in the wet July of that summer (Fig. 2). In the other populations, few runners were produced in 1977 and 1978, but the patterns of initiation generally matched those of 1976 . The percentage of plants producing at least one runner varied considerably from year to year (Table 3), but did not alone account for the variation in average number of runners per plant.

The number of plantlets (i.e., nodes with leaves) produced per plant (Table 5) generally followed the number of runners initiated, although the number of plantlets per runner was higher in the OPEN and Old-field HERB populations. The numbers of plantlets per plant that rooted and were independent by late fall tracked the plantlet production, but were also affected by ability to root successfully. Very high percentages of the plantlets at the OPEN site with its bare mineral soil were able to become established (Table 5). Establishment success at the other sites varied from year to year, often due to difficulties of the plantlets in reaching mineral soil.

Runner death sometimes occurred soon after runner initiation, perhaps due to herbivore attack. Most runners persisted until August, when they often dried up entirely, or at least the oldest section between the parent plant and the first plantlet died.

Runner stem dry mass varied from $0.1 \mathrm{~g} / \mathrm{m}$ for $F$. vesca to $0.3 \mathrm{~g} / \mathrm{m}$ for the heaviest $F$. virginiana stems at the OPEN site. $F$. virginiana plants from shady areas typically had lighter runners than plants in high-light areas. 
Table 4. Success of transitions between various stages of sexual reproductive development in each population. Values are \%

\begin{tabular}{|c|c|c|c|c|c|c|}
\hline & & OPEN & $\begin{array}{l}\text { Old-field } \\
\text { HERB }\end{array}$ & $\begin{array}{l}\text { Old-field } \\
\text { TRANS }\end{array}$ & $\begin{array}{l}\text { Old-field } \\
\text { SHRUB }\end{array}$ & $\begin{array}{l}\text { F. vesca } \\
\text { (FOREST) }\end{array}$ \\
\hline Buds to flowers & $\begin{array}{l}1976 \\
1977 \\
1978\end{array}$ & $\begin{array}{l}96.3 \\
92.7 \\
-\end{array}$ & $\begin{array}{l}- \\
96.8 \\
86.5\end{array}$ & $\begin{array}{l}85.2 \\
84.9 \\
75.0\end{array}$ & $\begin{array}{r}100.0 \\
87.7 \\
93.1\end{array}$ & $\begin{array}{r}97.8 \\
100.0 \\
100.0\end{array}$ \\
\hline Buds to green fruits & $\begin{array}{l}1976 \\
1977 \\
1978\end{array}$ & $\begin{array}{l}81.3 \\
62.7 \\
-\end{array}$ & $\begin{array}{l}- \\
47.2 \\
63.5\end{array}$ & $\begin{array}{r}23.5 \\
3.8 \\
16.7\end{array}$ & $\begin{array}{l}25.0 \\
35.1 \\
44.4\end{array}$ & $\begin{array}{l}66.7 \\
76.9 \\
85.0\end{array}$ \\
\hline Buds to ripe fruits & $\begin{array}{l}1976 \\
1977 \\
1978\end{array}$ & $\begin{array}{l}75.7 \\
60.0 \\
-\end{array}$ & $\begin{array}{l}- \\
36.8 \\
39.2\end{array}$ & $\begin{array}{r}6.2 \\
1.9 \\
13.9\end{array}$ & $\begin{array}{r}0.0 \\
14.0 \\
25.0\end{array}$ & $\begin{array}{l}40.0 \\
61.5 \\
15.0\end{array}$ \\
\hline Flowers to green fruits & $\begin{array}{l}1976 \\
1977 \\
1978\end{array}$ & $\begin{array}{l}84.5 \\
67.6 \\
-\end{array}$ & $\begin{array}{l}- \\
48.8 \\
73.4\end{array}$ & $\begin{array}{r}27.5 \\
4.4 \\
22.2\end{array}$ & $\begin{array}{l}25.0 \\
40.0 \\
47.8\end{array}$ & $\begin{array}{l}68.2 \\
76.9 \\
85.0\end{array}$ \\
\hline Green fruits to ripe fruits & $\begin{array}{l}1976 \\
1977 \\
1978\end{array}$ & $\begin{array}{l}93.1 \\
95.7 \\
-\end{array}$ & $\begin{array}{l}- \\
78.0 \\
61.7\end{array}$ & $\begin{array}{l}26.3 \\
50.0 \\
83.3\end{array}$ & $\begin{array}{r}0.0 \\
40.0 \\
56.3\end{array}$ & $\begin{array}{l}60.0 \\
80.0 \\
17.6\end{array}$ \\
\hline
\end{tabular}

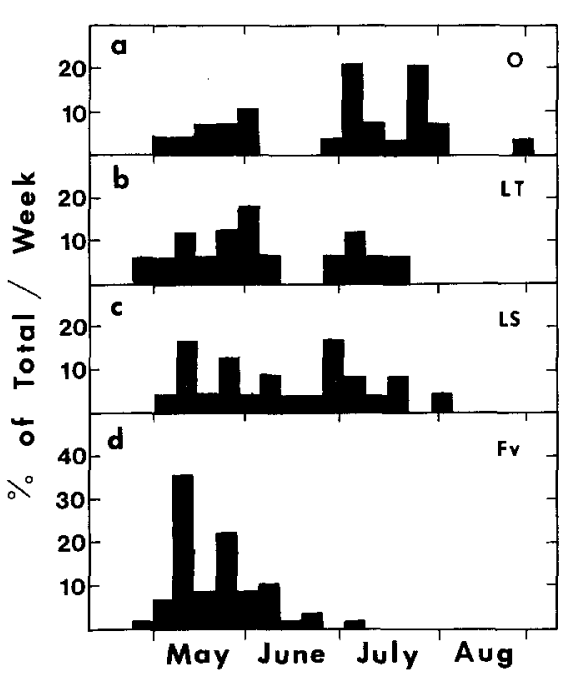

Fig. 2a-d. Time of appearance of runners, 1976. Graphs show the proportion (in \%) of runners appearing in each 7-day interval. Percentages are based on the total number of runners produced by the given population. a OPEN, b Old-field TRANS, c Old-field SHRUB, $\mathbf{d} F$. vesca (FOREST)

\section{Seedlings}

Over the course of this study, I found no recruitment of seedlings into the populations. Although seedlings could have appeared and died between my site visits, and I could have overlooked very young seedlings, none persisted long enough to be identifiable as an established recruit. In a larger-scale demographic study of strawberries at five other sites in the Ithaca area, Angevine (1981) also never observed recruitment of seedlings. Strawberry seedlings do, however, occasionally appear on sites in the Ithaca area where the original vegetation has been removed and mineral soil is exposed (Jurik, personal observations).

\section{$\mathrm{CO}_{2}$ exchange}

Net $\mathrm{CO}_{2}$ exchange rates of sexual reproductive organs in various stages of development from flower bud to ripe fruit are shown in Figs. 3-5. Dark respiration per unit dry mass was highest in flower buds and progressively decreased through development to the ripe fruit stage. Flower buds also exhibited the greatest increase in rate as temperature increased, i.e., they had the highest $\mathrm{Q}_{10} . \mathrm{Q}_{10}$ progressively decreased through development, with flower buds, flowers, green fruits, and ripe fruits having values of $2.3,2.25,2.15$, and 2.0 , respectively.

Flower buds exhibited an appreciable capacity for photosynthesis; flowers, green fruits, and white fruits had successively lower photosynthetic rates, while ripe fruits had only barely detectable rates (Figs. 3-5). Net $\mathrm{CO}_{2}$ exchange in light largely followed the dark respiration curves, especially for the developing fruits, although the changing distances between the light and dark curves indicate that photosynthesis had a temperature response different from the dark respiration response. Pistillate and hermaphrodite flowers had no appreciable differences in $\mathrm{CO}_{2}$ exchange rates (Fig. 4).

Pooled runner stem material of various ages had net $\mathrm{CO}_{2}$ exchange rates of -1.8 to $-2.0 \mathrm{mg} \mathrm{g}^{-1} \mathrm{~h}^{-1}$ at $22-25^{\circ} \mathrm{C} . \mathrm{Q}_{10}$ 's of 1.5 to 1.7 were typical for runners measured in late summer, but the seasonal course of temperature response was not investigated in detail.

Flower stalks were arbitrarily assigned the same response curve used for runners, since difficulties with excessive wounding of tissue made direct measurements untrustworthy. Plantlet organs were assigned the rates used for calculations with parent plants, as detailed in Jurik (1980, 1983).

\section{Carbon calculations}

The appreciable photosynthetic capacity of the sexual reproductive organs, probably primarily due to the persistent sepals, reduced the net carbon cost to the parent plant of sexual reproduction. For any given organ or set of organs, gross costs equal $\mathrm{CO}_{2}$ in structural materials plus "growth" respiration plus maintenance respiration. Net costs equal gross costs minus photosynthesis. Photosynthesis accounted for $6-9 \%$ of gross total costs of sexual reproduction in the OPEN, Old-field HERB, and Old-field TRANS 
Table 5. Production of runners, nodes with leaves, and plantlets independent by November. Values in the same column followed by the same letter are not significantly different ( $P>0.05$; Student-Newman-Keuls test; \% column not tested)

\begin{tabular}{|c|c|c|c|c|c|c|c|c|c|}
\hline & & \multirow{2}{*}{$\begin{array}{l}\# \\
\text { plants }\end{array}$} & \multicolumn{2}{|l|}{$\#$ runners } & \multicolumn{2}{|l|}{$\#$ nodes } & \multicolumn{2}{|c|}{ \# established plantlets } & \multirow{2}{*}{$\begin{array}{l}\text { \# established } \\
\text { plantlets } \\
\text { per \# nodes (\%) }\end{array}$} \\
\hline & & & per plant & S.D. & per plant & S.D. & per plant & S.D. & \\
\hline Old-field HERB & $\begin{array}{l}1977 \\
1978\end{array}$ & $\begin{array}{l}14 \\
14\end{array}$ & $\begin{array}{l}0.79^{\mathrm{a}, \mathrm{b}} \\
0.21^{\mathrm{a}}\end{array}$ & $\begin{array}{l} \pm 0.70 \\
\pm 0.43\end{array}$ & $\begin{array}{l}1.93^{\mathrm{a}, \mathrm{b}} \\
0.50^{\mathrm{a}, \mathrm{b}}\end{array}$ & $\begin{array}{l} \pm 2.06 \\
\pm 1.02\end{array}$ & $\begin{array}{l}1.21^{\mathrm{a}} \\
0.36^{\mathrm{a}}\end{array}$ & $\begin{array}{l} \pm 1.67 \\
\pm 0.75\end{array}$ & $\begin{array}{l}63.0 \\
71.4\end{array}$ \\
\hline Old-field SHRUB & $\begin{array}{l}1976 \\
1977 \\
1978\end{array}$ & $\begin{array}{l}17 \\
15 \\
15\end{array}$ & $\begin{array}{l}1.41^{\mathrm{b}} \\
0.20^{\mathrm{a}} \\
0.20^{\mathrm{a}}\end{array}$ & $\begin{array}{l} \pm 1.18 \\
\pm 0.41 \\
\pm 0.56\end{array}$ & $\begin{array}{l}1.77^{\mathrm{a}, \mathrm{b}} \\
0.27^{\mathrm{a}} \\
0.067^{\mathrm{a}}\end{array}$ & $\begin{array}{l} \pm 1.95 \\
\pm 0.80 \\
\pm 0.26\end{array}$ & $\begin{array}{l}1.00^{\mathrm{a}} \\
0.20^{\mathrm{a}} \\
0.067^{\mathrm{a}}\end{array}$ & $\begin{array}{l} \pm 1.46 \\
\pm 0.56 \\
\pm 0.26\end{array}$ & $\begin{array}{r}56.7 \\
75.0 \\
100.0\end{array}$ \\
\hline F. vesca (FOREST) & $\begin{array}{l}1976 \\
1977 \\
1978\end{array}$ & $\begin{array}{l}45 \\
20 \\
16\end{array}$ & $\begin{array}{l}1.31^{\mathrm{b}} \\
0.35^{\mathrm{a}} \\
0.94^{\mathrm{b}}\end{array}$ & $\begin{array}{l} \pm 1.31 \\
\pm 0.59 \\
\pm 0.85\end{array}$ & $\begin{array}{l}1.02^{\mathrm{a}, \mathrm{b}} \\
0.50^{\mathrm{a}, \mathrm{b}} \\
0.50^{\mathrm{a}, \mathrm{b}}\end{array}$ & $\begin{array}{l} \pm 1.39 \\
\pm 1.00 \\
\pm 0.89\end{array}$ & $\begin{array}{l}0.31^{\mathrm{a}} \\
0.35^{\mathrm{a}} \\
0.38^{\mathrm{a}}\end{array}$ & $\begin{array}{l} \pm 0.82 \\
\pm 0.75 \\
\pm 0.62\end{array}$ & $\begin{array}{l}30.4 \\
70.0 \\
75.0\end{array}$ \\
\hline
\end{tabular}

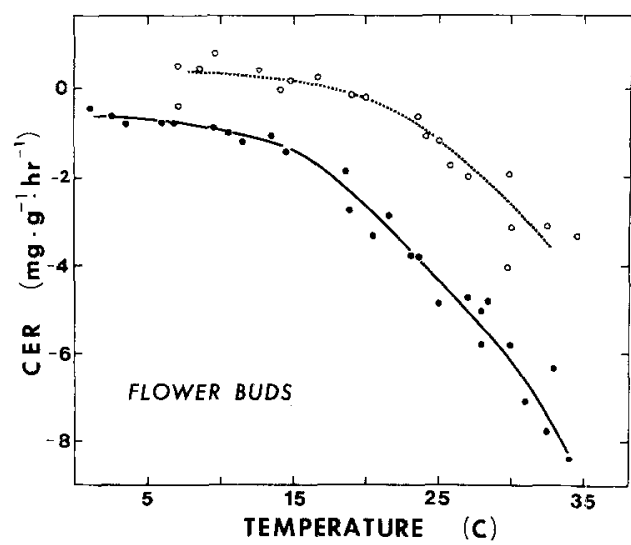

Fig. 3. Net $\mathrm{CO}_{2}$ exchange rate $(C E R)$ of detached flower buds. Data for three trials using different material are combined. - CER in the dark; o CER at $400-600 \mu \mathrm{E} \mathrm{m}^{-2} \mathrm{~s}^{-1}(400-700 \mathrm{~nm})$

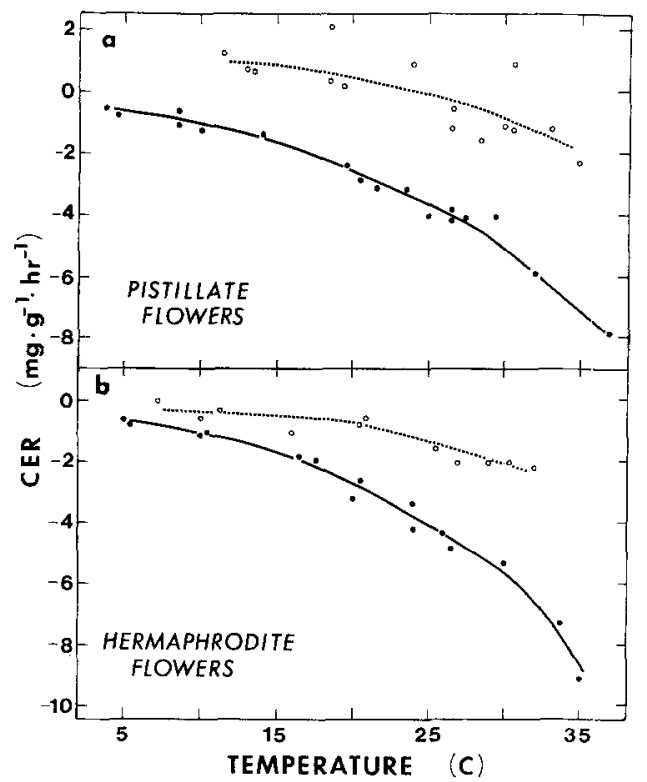

Fig. 4a, b. Net $\mathrm{CO}_{2}$ exchange rate (CER) of detached flowers. Data for three trials using different material are combined, a Pistillate flowers, b Hermaphrodite flowers. CER in the dark; O CER at $400-600 \mu \mathrm{E} \mathrm{m}^{-2} \mathrm{~s}^{-1}(400-700 \mathrm{~nm})$

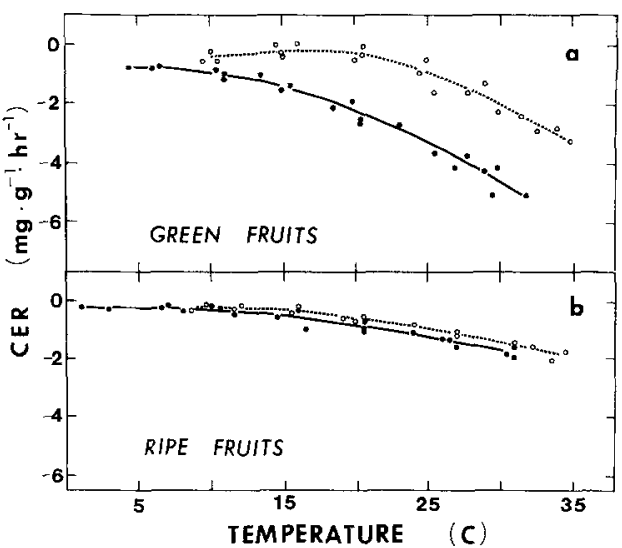

Fig. 5a, b. Net $\mathrm{CO}_{2}$ exchange rate $(C E R)$ of detached fruits. Data for three trials using different material are combined. a Green fruits, b Ripe fruits. $\bullet$ CER in the dark; O CER at $400-600 \mu \mathrm{E} \mathrm{m}^{-2} \mathrm{~s}^{-1}$ $(400-700 \mathrm{~nm})$

populations (Table 6), whereas the more shaded Old-field SHRUB and $F$. vesca populations had lower photosynthetic gains. Individual organ types differed widely in their ratios of photosynthesis to gross total costs (Table 6), with flowers having the highest ratio. This was due primarily to the relatively low costs of maintenance respiration in the flowers, while the total costs of most other organs included considerable costs for new structural material and growth respiration.

The net total costs of sexual reproduction were greatest in the Old-field HERB population (Table 7), even though the OPEN population produced the most ripe fruits (see Table 2). The Oldfield HERB population had large flower stalks, the most flower buds and flowers, and the largest fruits, but had lower success than the OPEN population in converting green fruits into ripe fruits (see Table 4). The Old-field HERB population thus had the highest net total costs without producing the most ripe fruits. Reduced numbers of flowers and fruits, reduced size of fruits, and variable photosynthetic gain combined to decrease the net total costs in the other populations (Table 7). Fruits accounted for a large fraction of the net total costs in the 
Table 6. Ratio (\%) of photosynthesis to gross costs for sexual reproductive organs. Ratios for each type of organ are based on the photosynthesis and gross costs of that type. The ratio for all organs is based on total photosynthesis summed over all types of organs divided by total costs summed over all types. Values are averages for two or three years. "Growing fruits" includes the green and white stages defined in the text

\begin{tabular}{|c|c|c|c|c|c|c|}
\hline & \multicolumn{5}{|c|}{ PS/gross costs $(\%)$} & \multirow{2}{*}{$\begin{array}{l}\text { Total PS } \\
\div \text { total } \\
\text { costs (all } \\
\text { organs) }\end{array}$} \\
\hline & $\begin{array}{l}\text { flower } \\
\text { stalks }\end{array}$ & $\begin{array}{l}\text { flower } \\
\text { buds }\end{array}$ & flowers & $\begin{array}{l}\text { growing } \\
\text { fruits }\end{array}$ & $\begin{array}{l}\text { ripe } \\
\text { fruits }\end{array}$ & \\
\hline $\begin{array}{l}\text { OPEN } \\
1976-77\end{array}$ & $<0.1$ & 8.4 & 48.2 & 8.1 & $<0.1$ & 8.4 \\
\hline $\begin{array}{l}\text { Old-field } \\
1977-78\end{array}$ & $<0.1$ & 8.4 & 41.6 & 5.3 & $<0.1$ & 6.3 \\
\hline $\begin{array}{l}\text { Old-field } \\
\text { TRANS } \\
\text { 1976-78 }\end{array}$ & $<0.1$ & 9.3 & 54.8 & 10.2 & $<0.1$ & 8.9 \\
\hline $\begin{array}{l}\text { Old-field } \\
\text { SHRUB } \\
1976-78\end{array}$ & $<0.1$ & 4.2 & 21.3 & 3.9 & $<0.1$ & 3.6 \\
\hline $\begin{array}{l}F . \text { vesca } \\
\text { (FOREST) } \\
1976-78\end{array}$ & $<0.1$ & 4.5 & 11.9 & 1.5 & $<0.1$ & 1.5 \\
\hline
\end{tabular}

Table 7. Net costs per plant of sexual reproductive organs, as a fraction of the total net costs of all sexual reproductive organs. (Net cost $=$ Total cost - PS; see text). Values are averages for two or three years

\begin{tabular}{|c|c|c|c|c|c|c|}
\hline & \multicolumn{5}{|c|}{ Net cost/Total net costs $(\%)$} & \multirow{2}{*}{$\begin{array}{l}\text { Total } \\
\text { net } \\
\text { costs } \\
(\mathrm{mg} \mathrm{CO})\end{array}$} \\
\hline & $\begin{array}{l}\text { flower } \\
\text { stalks }\end{array}$ & $\begin{array}{l}\text { flower } \\
\text { buds }\end{array}$ & flowers & $\begin{array}{l}\text { growing } \\
\text { fruits }\end{array}$ & $\begin{array}{l}\text { ripe } \\
\text { fruits }\end{array}$ & \\
\hline $\begin{array}{l}\text { OPEN } \\
1976-77\end{array}$ & 16.8 & 18.5 & 2.7 & 57.3 & 4.8 & 480 \\
\hline $\begin{array}{l}\text { Old-field } \\
\text { HERB } \\
1977-78\end{array}$ & 18.2 & 18.6 & 2.6 & 56.1 & 4.5 & 653 \\
\hline $\begin{array}{l}\text { Old-field } \\
\text { TRANS } \\
1976-78\end{array}$ & 52.2 & 38.4 & 4.2 & 5.1 & $\sim 0$ & 132 \\
\hline $\begin{array}{l}\text { Old-field } \\
\text { SHRUB } \\
1976-78\end{array}$ & 46.6 & 28.9 & 7.1 & 15.9 & 1.5 & 217 \\
\hline $\begin{array}{l}\text { F. vesca } \\
\text { (FOREST) } \\
1976-78\end{array}$ & 60.0 & 14.4 & 4.1 & 21.5 & $\sim 0$ & 156 \\
\hline
\end{tabular}

OPEN and Old-field HERB populations, while the lower numbers of fruits in other populations were reflected in shifts in the fraction of net total costs, with flower stalks and flower buds accounting for proportionately more of the net total costs (Table 7).

The calculated costs of producing one plantlet in each environment are shown in Table 8. Runner stem costs for one plantlet varied mainly according to differences in length and in mass per unit length. The $F$. vesca population had lower runner costs mainly because of decreased mass per unit length. The OPEN population had the lowest costs
Table 8. $\mathrm{CO}_{2}$ calculations for one plantlet. Net costs are incurred until plantlets become self-supporting and until runner stems die. Plantlet organ net costs $=$ plantlet organ gross costs - photosynthesis (PS). Runner stem net costs = runner stem gross costs. PS/(Total gross costs) is calculated using the sum of plantlet organ and runner stem gross costs. To get the actual average net costs per parent plant in the field, multiply plantlet net costs by the value in column 5

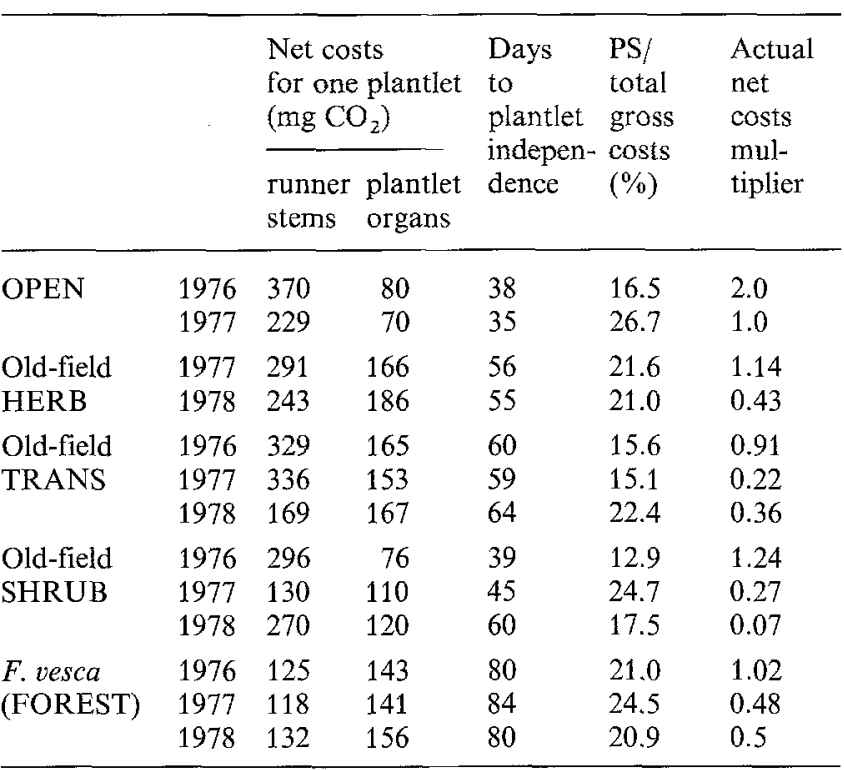

for producing a plantlet (node) because plantlets were relatively quickly able to support themselves (Table 8), so that costs to the parent were accrued over a shorter time, as compared to the other populations. Photosynthesis of the plantlets before independence accounted for $13-27 \%$ of the gross total costs of producing a plantlet (Table 8), with the fraction varying according to light level, size of runner plantlet, and amount of runner stems.

The total benefits to the parent plant from its investments in sexual and vegetative reproduction can be calculated by combining the costs of reproduction, as shown above, with demographic data from the populations. The number of seeds produced per plant is shown in Table 9. The net total carbon cost to the parent plant of producing a seed is considered to be the sum of all the investments in biomass and respiration of sexual reproductive structures required to produce the seed, minus any photosynthetic gain. On this basis, cost per seed was lowest in the OPEN population, slightly higher in the Old-field HERB population, and highest and most variable in the other populations (Table 9). A similar cost calculation for achieved seedlings would be very interesting, but cannot be made without more extensive data on seedling recruitment. The zero seedling recruitment in this study suggests that the cost per seedling is extremely high.

As discussed in Methods, the benefits of an investment in a plantlet can be considered to be the total number of plantlets resulting from the initial investment by the parent plant. By further combining these plantlet production data with plantlet survivorship data, the cost of a plantlet alive after a certain time can be calculated. The net carbon cost per plantlet based on all plantlets produced divided by the net investment of the parent plant was lowest in the OPEN population (Table 9). Differential ability to become rooted 
Table 9. $\mathrm{CO}_{2}$ costs of seeds and plantlets. Cost per seed is based on total net costs of sexual reproductive structures (Table 7). Plantlet costs are based on all plantlets resulting from the initial investment (Table 8) of the parent plant. Cost values are $\mathrm{mg} \mathrm{CO}_{2}$

\begin{tabular}{|c|c|c|c|c|c|c|}
\hline & & $\begin{array}{l}\text { Seeds } \\
\text { per } \\
\text { plant }\end{array}$ & $\begin{array}{l}\text { Cost } \\
\text { per } \\
\text { seed }\end{array}$ & $\begin{array}{l}\text { Cost } \\
\text { per } \\
\text { plant- } \\
\text { let }\end{array}$ & $\begin{array}{l}\text { Cost per } \\
\text { plantlet } \\
\text { estab- } \\
\text { lished } \\
\text { by fall }\end{array}$ & $\begin{array}{l}\text { Cost per } \\
\text { plantlet } \\
\text { alive } \\
\text { in fall } \\
\text { of second } \\
\text { year }\end{array}$ \\
\hline OPEN & $\begin{array}{l}1976 \\
1977\end{array}$ & $\begin{array}{l}111 \\
104\end{array}$ & $\begin{array}{l}4.6 \\
4.3\end{array}$ & $\begin{array}{r}90 \\
112\end{array}$ & $\begin{array}{l}102 \\
119\end{array}$ & $\begin{array}{l}108^{a} \\
131\end{array}$ \\
\hline $\begin{array}{l}\text { Old-field } \\
\text { HERB }\end{array}$ & $\begin{array}{l}1977 \\
1978\end{array}$ & $\begin{array}{r}123 \\
94\end{array}$ & $\begin{array}{l}5.8 \\
6.4\end{array}$ & $\begin{array}{l}271 \\
368\end{array}$ & $\begin{array}{l}432 \\
511\end{array}$ & $\begin{array}{l}458 \\
859\end{array}$ \\
\hline $\begin{array}{l}\text { Olf-field } \\
\text { TRANS }\end{array}$ & $\begin{array}{l}1976 \\
1977 \\
1978\end{array}$ & $\begin{array}{l}11 \\
1.5 \\
5\end{array}$ & $\begin{array}{l}17.9 \\
77.2 \\
16.9\end{array}$ & $\begin{array}{l}493 \\
486 \\
336\end{array}$ & $\begin{array}{r}3450 \\
629 \\
526\end{array}$ & $\begin{array}{r}5160 \\
1230 \\
887\end{array}$ \\
\hline $\begin{array}{l}\text { Old-field } \\
\text { SHRUB }\end{array}$ & $\begin{array}{l}1976 \\
1977 \\
1978\end{array}$ & $\begin{array}{r}0 \\
11 \\
33\end{array}$ & $\begin{array}{l}\infty \\
21.3 \\
9.9\end{array}$ & $\begin{array}{l}260 \\
237 \\
390\end{array}$ & $\begin{array}{l}460 \\
320 \\
390\end{array}$ & $\begin{array}{l}652 \\
480 \\
390\end{array}$ \\
\hline $\begin{array}{l}\text { F. vesca } \\
\text { (FOREST) }\end{array}$ & $\begin{array}{l}1976 \\
1977 \\
1978\end{array}$ & $\begin{array}{r}22 \\
21 \\
4\end{array}$ & $\begin{array}{r}8.0 \\
7.9 \\
31.7\end{array}$ & $\begin{array}{l}269 \\
258 \\
288\end{array}$ & $\begin{array}{l}884 \\
351 \\
379\end{array}$ & $\begin{array}{r}1540 \\
351 \\
576\end{array}$ \\
\hline
\end{tabular}

a OPEN 1976 based on number alive in spring of second year

and possibly other factors caused differences in the proportion of plantlets able to become established by fall of their first year (see Table 5). The cost per plantlet established by fall varied among the populations, with the OPEN population again having the lowest cost (Table 9). The poorer survivorship of the Old-field and $F$. vesca plantlets resulted in relatively greater increases in costs, as compared to the costs based on all plantlets produced. By fall of the plantlets' second year, differential survivorship (see Jurik 1980) resulted in further increases in cost per plantlet alive at that time, with the OPEN plantlets again having the lowest costs.

\section{Discussion}

The photosynthetic gain of the sexual reproductive organs was typically less than $1 \%$ of the total $\mathrm{CO}_{2}$ gain of the entire plant for the year (Jurik 1980, 1983). However, in the $F$. virginiana populations, this photosynthate paid for $49 \%$ of the costs of the reproductive structures (Table 6). Furthermore, such photosynthate may be especially valuable because it is produced during a period of high demand for growth substrates. The relatively high photosynthetic contributions of plantlets toward their own costs (Table 8), even in the restricted period used in these calculations, also demonstrate the importance of photosynthesis in reproductive structures. Other species may have even greater photosynthetic contributions from reproductive structures; Bazzaz and Carlson (1979) calculated that assimilation by reproductive structures could pay for $41 \%$ and $57 \%$ of the carbohydrate required to produce male and female inflorescences of Ambrosia trifida plants grown experimentally in high-light conditions. In a study of 15 tree species, Bazzaz et al. (1979) found that photosynthesis of reproductive structures ranged from 2.3 to $64.5 \%$ of total costs of producing mature seed.
The costs of seeds and plantlets varied among populations. While the actual values of the calculated costs may vary slightly both because of the methods used for data collection and the calculations and because of year-to-year variation, the general trend of increasing costs with increasing vegetative cover (or with decreasing resource availability) seems to be a much larger factor. The study years should be regarded as estimates of the long-term average of costs in a specific type of environment. Selection over evolutionary time may be atuned to the long-term pattern of conditions in a given type of environment, e.g., a pattern for strawberry of considerable year-to-year variation in conditions, with concomitant "good" years and "poor" years for fruit production. The costs of reproduction in a given environment as calculated here should be based on the longterm probability of resource availability or pollinator efficiency or whatever factors proximately control reproduction. It is in this sense that calculations for the years of this study estimate the long-term probable costs of producing propagules in each type of habitat. Since seedlings and plantlets differ in genetic importance and colonizing ability, it is unfortunate that, without more extensive data on seedling recruitment, the costs of seedlings and plantlets cannot be compared.

The study of reproductive effort, or the fraction of resources allocated to reproduction, is a fundamental aspect of the study of life history patterns (Stearns 1976). There has been considerable discussion of why certain levels of reproductive effort have evolved in given species and habitats (Gadgil and Solbrig 1972; Schaffer 1974; Stearns 1977; Pitelka 1977; Abrahamson 1979). Beyond the consideration of why a certain level, or range, of reproductive effort may have evolved lies the more specific question of how a given reproductive effort can best be split up among offspring (see Smith and Fretwell 1974). In simple form, the question is: "Should a few large offspring or many small offspring be produced?" Even greater complexity is introduced when a species has multiple modes of reproduction available, since the size/number question still applies but with the additional complication that an optimal solution must now balance the costs and benefits of the modes of reproduction.

This study suggests an additional problem to be considered when evaluating reproductive effort, namely, the changing cost of a given type and size of offspring in different environments. The size/number and other questions still apply, but instead of assuming a constant cost in different environments for a given type of propagule, analyses of such questions should use a cost function. The net cost of a seed of constant size, for example, may vary according to the type of environment in which it is produced; this is the cost function that must be defined. The carbon costs of reproduction calculated here are estimates of the costs in each environment of producing propagules of approximately equivalent initial value. Taken together, they estimate the carbon cost functions for sexual and vegetative reproduction in strawberry. Studies of reproductive effort typically have not dealt with variation in cost of propagules, with Kawano and Masuda (1980) a notable exception. Kawano and Masuda found that the ratio of seed biomass to other reproductive biomass changed in populations of Heloniopsis orientalis along an elevation gradient. Such changes imply variable propagule costs, since biomass is a major portion of the total $\mathrm{CO}_{2}$ costs of producing and maintaining plant organs (Jurik 1980). 
The cost function may have its own effect on life history parameters. For example, it might be of overall benefit to a strawberry genotype to have highest sexual reproductive effort in open habitats with high energy availability, as indeed strawberries do have (Jurik 1983), simply because the cost per seed is lowest in such environments. Lower cost per seed is equivalent to greater return per unit investment. For a genotype encountering a series of environments on a site during the course of vegetational succession, the optimal total seed yield might be achieved by investing relatively more where the return on investment is greatest, i.e., the largest sexual reproductive effort might occur in an earlysuccessional, open habitat. The value of the many seeds produced on an open site may outweigh a potential decrease in the rate of colonizing the site via plantlets, since once the site is overgrown by other species the cost per seed will increase and the total number of seeds that can be produced will greatly decrease.

The above prediction differs from that often made for plants possessing both sexual and vegetative reproduction. For example, the strawberry-coral model of Williams (1975) predicts high vegetative and low sexual reproductive effort in open habitats, where rapid colonization would be aided by high vegetative reproduction. As habitats become more closed, a reversal of effort is expected, with sexual reproductive effort favored for production of new genotypes and dispersal units (Smith 1972; Williams 1975; Holler and Abrahamson 1977). In natural habitats, strawberry does show a relative increase in the ratio of sexual reproductive effort to vegetative reproductive effort as environments become more closed (Jurik 1983), but only because vegetative reproductive effort decreases more than sexual reproductive effort decreases. Similarly, in an experimental investigation, Holler and Abrahamson (1977) found vegetative reproductive effort to decline with increased density, while sexual reproductive effort remained constant. Studies with other species have generally found vegetative reproductive effort to decrease with increased "density" (Ogden 1974; Abrahamson 1975), although Aster acuminatus has little variation with density (Pitelka et al. 1980; Winn and Pitelka 1981). Sexual reproductive effort has been found to decrease (Hayashi and Kawano, unpublished, in Kawano 1975; Weiss 1978), remain constant (Ogden 1974), increase (Abrahamson 1975), or vary in a complex manner (Pitelka et al. 1980; Thompson and Beattie 1981; Winn and Pitelka 1981) with increased density. Thus, the general relationship between sexual reproductive effort, vegetative reproductive effort, and environment is not yet clearly understood; analyses of costs of propagules for other species could be helpful in clarifying the apparent contradictions.

I do not claim the cost effect to be the sole, or even a major, factor determining reproductive effort; I do suggest that it may have some hitherto neglected role in determining evolved levels of reproductive effort. While carbon may or may not be the appropriate unit of cost measurement (cf. Thompson and Stewart 1981; Abrahamson and Caswell 1982), the calculations do illustrate that costs of equivalent value reproductive propagules may be different in various habitats; such differences should be considered in theoretical treatments of reproductive effort and life histories.

Acknowledgements. I thank Brian Chabot for his guidance throughout the course of this study and C.L. Jolls for helpful comments on the manuscript. This research was partially supported by grants from the Section of Ecology and Systematics, Cornell University.

\section{Appendix}

Fernald (1950) describes the genus Fragaria as polygamodioecious. Although J.F. Chabot (pers. comm.) has distinguished three types of $F$. virginiana flowers in the Ithaca area (staminate, pistillate, and hermaphrodite), in the Oldfield populations I could distinguish only two types. Flowers with greatly reduced stamens and slightly smaller petals were easily distinguished from apparently perfect, hermaphrodite flowers. The apparent hermaphrodites could have had non-functional pistils. Rarely, away from the permanently marked populations, I found a flower with greatly reduced pistils that could confidently be called staminate. Many of the apparent hermaphrodites did succeed in setting fruit in at least one year, and also produced noticeable amounts of pollen. Individual plants produced only one type of flower, and were constant from year to year. Although not all plants flowered, the populations probably did differ in types of flowers present. The Old-field HERB population had exclusively pistillate flowers, while $90 \%$ of the Old-field TRANS population had hermaphrodite flowers. The Old-field Shrub population was $62 \%$ hermaphrodite and $38 \%$ pistillate; no data are available for the OPEN population. The two categories of flowers in the Old-field Shrub population set fruit about equally well. The apparent hermaphrodite flowers of the Old-field TRANS population did occasionally set fruit. The flowers of $F$. vesca were all apparent hermaphrodites, although the stamens were shorter and the pistils more prominent than in hermaphrodite flowers of $F$. virginiana. Crossing trials (Angevine 1981) have shown that flowers of $F$. vesca often are self-fertile, although not apomictic.

Flower dry mass of $F$. virginiana averaged $12.5 \mathrm{mg}$ per flower $( \pm 4.2, n=49)$ for hermaphrodite flowers and $8.4 \mathrm{mg}$ $( \pm 2.6, n=66)$ for pistillate flowers. The pistillate flowers had slightly smaller petals, but also seemed to have lighter receptacles. Flowers produced late in May appeared to be smaller than those produced in mid-May, although I have no data on this. Petals accounted for $39 \%$ of total pistillate flower mass and $56 \%$ of hermaphrodite flower mass, as estimated from the difference in mass between flowers which had just lost their petals and complete flowers.

Mass increase of enlarging fruits was followed by regressing size against mass. I divided fruit development into three reasonably distinct stages: 1 . Green fruits in which the receptacle is enlarging and both the achenes and the small area of the receptacle that is visible are green, 2 . White fruits in which the receptacle is white to pink and the achenes are green or red, and 3. Ripe fruits in which the receptacle is red and the achenes have hardened. Fruit dry mass, including sepals, was estimated by:

$$
\begin{aligned}
& \text { Green Fruit Mass }=0.0763 * \mathrm{~L} * \mathrm{D}+0.0005 \\
& \left(P<0.0001 ; n=31 ; \mathrm{r}^{2}=0.86\right) \\
& \text { White Fruit Mass }=0.0612 * \mathrm{~L} * \mathrm{D}+0.0057 \\
& \left(P<0.0001 ; n=75 ; \mathrm{r}^{2}=0.63\right) \\
& \text { Ripe Fruit Mass }=0.0730 * \mathrm{~L} * \mathrm{D}-0.0085 \\
& \left(P<0.0001 ; n=85 ; \mathrm{r}^{2}=0.83\right)
\end{aligned}
$$

where Mass is dry mass $(\mathrm{g}), \mathrm{L}$ is the fruit length $(\mathrm{cm})$, and $\mathrm{D}$ is the average maximum diameter $(\mathrm{cm})$. 


\section{References}

Abrahamson WG (1975) Reproductive strategies in dewberries. Ecology 56:721-726

Abrahamson WG (1979) Patterns of resource allocation in wildflower populations of fields and woods. Amer J Bot 66:71-79

Abrahamson WG, Caswell $\mathrm{H}$ (1982) On the comparative allocation of biomass, energy, and nutrients in plants. Ecology $63: 982-991$

Angevine M (1981) Demographic variation in populations of the wild strawberries Fragaria vesca and $F$. virginiana. Ph.D. dissertation, Cornell University, Ithaca, NY, p 149

Bazzaz FA, Carlson RW (1979) Photosynthetic contribution of flowers and seeds to reproductive effort of an annual colonizer. New Phytol 82:223-232

Bazzaz FA, Carlson RW, Harper JL (1979) Contribution to reproductive effort by photosynthesis of flowers and fruits. Nature 279:554-555

Darrow GM (1966) The strawberry: history, breeding, and physiology. Holt, Rinehart, and Winston. NY, p 447

Fernald ML (1950) Gray's manual of botany. D. Van Nostrand Co, p 1632

Gadgil M. Solbrig OT (1972) The concept of r- and K-selection: Evidence from wild flowers and some theoretical considerations. Amer Natur 106:14-31

Holler LC, Abrahamson WG (1977) Seed and vegetative reproduction in relation to density in Fragaria virginiana (Rosaceae). Amer J Bot 64:1003-1007

Jurik TW (1980) Physiology, growth, and life history characteristics of Fragaria virginiana Duchesne and $F$. vesca L. (Rosaceae). Ph.D. dissertation, Cornell University, Ithaca, NY, p 439

Jurik TW (1983) Reproductive effort and $\mathrm{CO}_{2}$ dynamics of wild strawberry populations. Ecology 64:1329-1342

Jurik TW, Chabot JF, Chabot BF (1982) Effects of light and nutrients on leaf size, $\mathrm{CO}_{2}$ exchange, and anatomy in wild strawberry (Fragaria virginiana). Plant Physiol 70:1044-1048

Kawano S (1975) The productive and reproductive biology of flow- ering plants. II. The concept of life history strategy in plants. J College Liberal Arts Toyama Univ Japan 8:51-86

Kawano S, Masuda J (1980) The productive and reproductive biology of plants. VII. Resource allocation and reproductive capacity in wild populations of Heloniopsis orientalis (Thunb.) C. Tanaka (Liliaceae). Oecologia (Berlin) 45:307-317

Ogden J (1974) The reproductive strategy of higher plants. II. The reproductive strategy of Tussilago farfara L. J Ecol 62:291-324

Pitelka LF (1977) Energy allocation in annual and perennial lupines (Lupinus: Leguminosae). Ecology 58:1055-1065

Pitelka LF, Stanton DS, Peckenham MO (1980) Effects of light and density on resource allocation in a forest herb, Aster acuminatus (Compositae). Amer J Botany 67:942 948

Schaffer WM (1974) Optimal reproductive effort in fluctuating environments. Amer Natur 108:783-790

Smith CC (1972) The distribution of energy into sexual and asexual reproduction in wild strawberries (Fragaria virginiana). Proc Third Midwest Prairie Conference: 55-60

Smith CC, Fretwell SD (1974) The optimal balance between size and number of offspring. Amer Natur 108:499-506

Stearns SC (1976) Life-history tactics: a review of the ideas. Quarterly Rev Biol 51:3-47

Stearns SC (1977) The evolution of life-history traits: a critique of the theory and a review of the data. Ann Rev Ecol Syst $8: 145-171$

Thompson DA, Beattie AJ (1981) Density-mediated seed and stolon production in Viola (Violaceae). Amer J Botany 68:383-387

Thompson K, Stewart AJA (1981) The measurement and meaning of reproductive effort in plants. Amer Natur 117:205-211

Weiss PW (1978) Reproductive efficiency and growth of Emex australis in relation to stress. Austral J Ecol 3:57-65

Williams GC (1975) Sex and evolution. Princeton Univ Press

Winn A, Pitelka L (1981) Some effects of density on the reproductive patterns and patch dynamics of Aster acuminatus. Bull Torr Bot Club 108:438-445

Received May 1, 1984 